\title{
Statyba
}

\section{LITHUANIAN GRAVEL ROADS AND FEASIBILITY OF THEIR PAVING}

\section{K. Sakalauskas \& S. Skrinskas}

To cite this article: K. Sakalauskas \& S. Skrinskas (1998) LITHUANIAN GRAVEL ROADS AND FEASIBILITY OF THEIR PAVING, Statyba, 4:2, 134-142, DOI: 10.1080/13921525.1998.10531393

To link to this article: https://doi.org/10.1080/13921525.1998.10531393

曲 Published online: 26 Jul 2012.

Submit your article to this journal $₫$

Џ Article views: 100 


\title{
LITHUANIAN GRAVEL ROADS AND FEASIBILITY OF THEIR PAVING
}

\author{
K. Sakalauskas, S. Skrinskas
}

\section{Introduction}

Gravel roads comprise $48,6 \%$ of the total of $21,121 \mathrm{~km}$ of the State road network of Lithuania. The range of their condition is extremely wide. Pavement width vary from 4 to 12 meters, gravel pavement thickness vary from 0 to $80 \mathrm{~cm}$, average yearly road roughness vary from 5 to $14 \mathrm{~m} / \mathrm{km}$ IRI. Gravel roads are situated in a wide range of geomorphologic and hydrogeologic conditions and are affected by the different vehicle flows ranging from 40 to more than $1200 \mathrm{veh} /$ day AADT. The shift from the planned economy to the market economy has resulted in the decrease of the country's economic capacity and tenfold cuttings of budgetary allocations for the gravel road repairs and maintenance.

At the same time two of five road sector related objectives of the National Transportation Sector Development Program were connected with paving of gravel roads. One objective emphasised paving of gravel road sections leading through settlements, the other one planned paving of all gravel roads where AADT exceeds 500 veh/day. But these plans were not included into the three-year State Investment Program of 1995-1997, because of the lack of research on gravel roads data and because of the absence of locally applicable economic evaluation models. The importance and need of the system for management of maintenance and paving of gravel roads based on market economy criteria was obvious.

The article describes the research of the feasibility of paving gravel roads in Lithuania carried out in 1994-1997. The research comprised five major steps: 1) analysis of the world's most famous gravel road paving economic appraisal systems and models, 2) detailed analysis of condition of Lithuanian gravel roads, 3) inventory of the most common and reliable in local climatic conditions asphalt pavement structures, 4) building of a locally applicable gravel road paving economic feasibility evaluation mathematical model, and 5) testing and introduction of the new model in bodies of the Lithuanian Automobile Road Administration.

\section{Research objective}

The research objective was a scientific substantiation of common threshold values for paving gravel roads. The substantiation was done by building a mathematical model for evaluation of economic feasibility of paving gravel roads under current Lithuanian economic and climatic conditions.

In gaining the research objective, the following tasks were solved:

- the world's most famous gravel road condition evaluation and paving economic appraisal systems and models were analysed,

- according to a specially designed methodology detailed research and analysis of condition of gravel roads in Lithuania were performed (gravel pavement roughness was proven to be the most important road condition criteria),

- the most common and reliable in local climatic conditions asphalt pavement structures were analysed and compared with similar foreign practices,

- locally applicable gravel road paving economic feasibility evaluation mathematical model KAMIS was built for joint economic analysis of road paving and paved road maintenance expenses, gravel road maintenance, road users and environmental cost savings,

- model was tested and introduced in the Lithuanian Automobile Road Administration.

\section{Research scope, methodologies and findings}

Theoretic, experimental, road engineering and economic research planning and implementation stages were related to different scopes and were struc- 
tured on different methodological grounds. Major research fields are presented separately.

\subsection{Theoretic research}

Theoretic research was designed to build an accurate frame for sound implementation of the major research objective and adequate completion of all the secondary tasks and sub-tasks. Theoretic analysis was also associated with a lot of previously obtained research results and their comparison with the local technical requirements. The outcomes of a limited investment into gravel roads and the problematic nowadays application of the subjective multiparameter road condition evaluation systems were analysed in detail. The overview of the major international programs and separate research studies was concentrated into the analysis of the gravel pavement roughness and its relationships to a variety of road technical, climatic, maintenance and traffic parameters. The TRRL research in Africa, GEIPOT and World Bank studies in Brazil and the data from South African SURF model were compared on a basis of pavement roughness related matters.

In total more than one hundred publications in English, Russian, Lithuanian, Finnish and Faeroes on the subjects of gravel roads and their renovation were analysed or reviewed.

\subsection{Experimental research}

Research methodology covered principles of the selection of gravel road test regions and sections. It was foreseen that experimental research results should be of an adequate accuracy to reach the research tasks. It was also planned that the research should cover the best and the worst road maintenance conditions, different (but prevailing in the country) geomorphologic areas, different (but prevailing) quality and genesis of local gravel material, but should be executed in the major climatic regions with an average rainfall, and should represent countries data averages. The countries third best (Ukmerge) and the second worst (Kaišiadorys) maintenance regions met all stated requirements. In each of the regions five 3.0-3.3 $\mathrm{km}$ length test sections in the best, the worst, one with the most intensive traffic, average reconstructed and average not reconstructed gravel road sections were selected. Five additional 2.55-5.0 km gravel road sections in Kaišiadorys, Ukmergè and Kelmè regions were included for the reasons of calibration of a roughness measuring device, former regular traffic counting places and measurements of roughness increase after blading.

The length of the test sections - app. $3 \mathrm{~km}$ - more than 10 times exceed the practice from other similar (primarily roughness) surveys, but gave less bias and more accurate results.

Experimental research included traffic surveys, gravel road condition research, and road roughness measurements. Traffic surveys were executed in order to identify the actual traffic volumes on Lithuanian gravel roads and to measure the traffic flow composition in order to use the research data for estimation of vehicle operating costs. Surveys were organised in 1994-1995 and comprised two stages: traffic counts on the test sections and traffic surveys on the preselected as with the most intensive traffic gravel roads in the 39 of 44 Lithuanian regions. Traffic surveys on 15 test sections were done according to the recommendations of Finnish National Road Administration (128 hours/year). Traffic surveys on other 225 gravel road sections ( 88 of them loads through settlements) were organised according to the methodology developed by "Transport and Road Research Institute" (6 hours/year). Both traffic surveys totalled 555 counts and lasted 3149 hours (or 151 day and 5 hours).

Research results showed that AADT on gravel roads in 1994-1995 ranged from 40 to $1080 \mathrm{veh} /$ day. The highest traffic in gravel roads in settlements reached $850 \mathrm{veh} /$ day. Research results showed that AADT exceeded in 1994-1995 known figures and that according to the objectives of the National Transportation Sector Development Program gravel road paving works were to be done on $125 \mathrm{~km}$ of gravel roads, where AADT exceeded $500 \mathrm{veh} /$ day and on $117 \mathrm{~km}$ of gravel roads leading through settlements. AADT in Kaišiadorys region gravel roads was $261 \mathrm{veh} /$ day, in Ukmergè region it reached $158 \mathrm{veh} /$ day.

It was found that light cars $(47.2 \%)$, medium trucks $(13.6 \%)$ and tractors $(12.8 \%)$ occupied the major portion of the traffic flow on gravel roads.

Gravel road condition research was aimed at an investigation of an actual condition of state gravel roads and to compare findings with the requirements of design standards and regulations. Gravel road technical condition directly affect expenses required for road paving. Condition research consists of: road width and gravel pavement thickness measurements, pavement gravel mixture composition (including per- 
centage of clay, dust and silt) research, embankment and drainage system inspection and measurements of the stopping sight distance. Total of 129 sets of technical condition evaluation tests were executed on the chosen gravel road sections.

Condition research results showed that $60 \%$ of gravel roads meet the technical requirements of design standards. These results also proved that in $19.7 \%$ of the length of gravel roads additional works for extending the sight distance in case of paving would be required. It was estimated that $48.2 \%$ of Lithuanian gravel roads could be paved without their reconstruction, and required changes in a base course mixture composition could be made with a help of a specially designed aggregate mixture composition of a leveling course.

Road roughness measurements had four major tasks: 1) to get exact figures on longitudinal pavement roughness according to the International Roughness Index (IRI) scale, 2) to analyse, if roughness reflects other gravel road condition parameters, 3) to estimate the curve of roughness progression after blading in order to make recommendations for simplified roughness measurements, 4) to get accurate data for further economic analysis. The first task comprised two stages - roughness measurements on the selected gravel road sections using Russian made towed bump integrator PKRS-2 $u$ and research on the relationship between the PKRS-2u and IRI measurement scales. The first stage totalled 312 roughness measurements (both directions each time) before and after blading, on which $922.2 \mathrm{~km}$ of gravel roads were metered in the period from March to October, 1994. During the second stage 420 roughness measurements (252 of which on gravel roads) were done on $126 \mathrm{~km}$ of gravel $(75.6 \mathrm{~km})$ and paved roads TRRL designed MERLIN device was used as a reference to IRI scale.

Research on the relationship between the PKRS$2 \mathrm{u}$ and IRI measurement scales resulted in two equations. Relationship between PKRS-2u and IRI scales for gravel roads was expressed by equation 1 [1]:

$$
S_{G R-I R I}=-2.74+0.61 S_{P K R S-2 u}, \mathrm{~m} / \mathrm{km}
$$

where

$S_{G R-I R I}$ is gravel road roughness according to IRI scale, $m / k m$;

$S_{P K R S-2 u}$ is gravel road roughness according to PKRS-2u scale, $\mathrm{m} / \mathrm{km}$
Equation 1 was valid $\left(R^{2}>0.7\right.$ ) only when gravel road roughness was between 3.4 and $12 \mathrm{~m} / \mathrm{km}$ IRI or between 10 and $24 \mathrm{~m} / \mathrm{km}$ PKRS-2u, as well as when wheel tracks were free from the loose aggregates of more than $2 \mathrm{~mm}$ diameter.

Relationship between PKRS-2u and IRI scales for asphalt roads was expressed by equation 2 [1]:

$$
S_{A-I R I}=-0.91+0.51 S_{P K R S-2 u}, \mathrm{~m} / \mathrm{km}
$$

where

$S_{A-I R I}$ is asphalt road roughness according to IRI scale, $m / k m$.

After transferring the measurement data into the IRI scale, a curve of roughness progression after blading was estimated. The curve was based on the results from three test sections with an average AADT of $325 \mathrm{veh} /$ day, and was expressed according to the formula 3 [2]:

$$
R_{(d)}=R_{0}+0.95 d^{1 / 2}, m / k m
$$

where

$R_{(d)}$ is gravel road roughness in d days after the last blading, $\mathrm{m} / \mathrm{km}$ IRI;

$R_{0}$ is gravel road roughness after blading, $\mathrm{m} / \mathrm{km}$ IRI.

Final roughness and other main results of gravel road condition research are presented in Table 1.

Results presented in the table proved that roughness reflects other gravel road condition parameters and could be used as a major condition evaluation criteria. Based on roughness valuation according to the World bank requirements it was estimated, that $42 \%$ of state gravel roads were in good condition, $40 \%$ satisfactory and $18 \%$ poor. In comparison with other world regions, gravel roads conditions in Lithuania in general were better.

Results, presented in experimental research, led to the conclusion that the situation of a wide range of gravel road condition required first steps in developing simple gravel road management system. AADT data comparison with the objectives of the National Transportation Sector Develop-ment Program justified the importance of creation of a model for evaluation of an economic feasibility of paving gravel roads. 
Table 1. Results of the major parameters of Lithuanian gravel roads condition research

\begin{tabular}{|c|c|c|c|c|c|c|}
\hline $\begin{array}{l}\text { Studied parameters } \\
\text { and test regions }\end{array}$ & $\begin{array}{l}\text { AADT, } \\
\text { veh/day }\end{array}$ & $\begin{array}{c}\text { Pavement } \\
\text { width, } \\
\mathrm{m}\end{array}$ & $\begin{array}{c}\text { Pavement } \\
\text { thickness, } \\
\mathrm{cm}\end{array}$ & $\begin{array}{l}\text { Matching the stan- } \\
\text { dard mixture } \\
\text { composition, \% }\end{array}$ & $\begin{array}{c}\text { Clay, dust } \\
\text { and silt, } \\
\%\end{array}$ & $\begin{array}{l}\text { Roughness } \\
\text { m/km IRI }\end{array}$ \\
\hline \multicolumn{7}{|l|}{ Kaišiadorys region } \\
\hline Mean & 261 & 9.4 & 29 & 70 & 7.6 & 9.9 \\
\hline Maximum & 750 & 12.2 & 47 & 90 & 9.8 & 12.5 \\
\hline Minimum & 90 & 7.4 & $14^{1}$ & 40 & 4.9 & 7.2 \\
\hline \multicolumn{7}{|l|}{ Ukmergè region } \\
\hline Mean & 158 & 7.0 & 49 & 80 & 8.6 & 6.5 \\
\hline Maximum & 300 & 10.3 & 67 & 100 & 5.6 & 9.4 \\
\hline Minimum & 60 & 5.5 & 24 & 40 & 10.7 & 5.6 \\
\hline \multicolumn{7}{|l|}{ Lithuania } \\
\hline $\mathrm{Mean}^{2}$ & 210 & 8.4 & 37 & 75 & 8.1 & 8.9 \\
\hline Maximum & 1080 & 12.2 & 67 & 100 & 10.7 & 12.5 \\
\hline Minimum & 40 & 5.5 & 14 & 40 & 4.9 & 5.6 \\
\hline
\end{tabular}

Remarks: ${ }^{1}$ - completely deteriorated gravel pavement was found in two spots of two different test sections of Kaišiadorys region, ${ }^{2}$ - estimation based on results from all test sections

\subsection{Road engineering research}

Before building a final economic evaluation model, several basic engineering decisions were made. Decisions were associated with the selection of asphalt pavement structures, gravel and paved road maintenance policies and with their economic valuation. Based on the inventory of the practices of paving gravel roads in Lithuania and experience of other similar climate countries (eg Russia, Finland and the State of Minnesota, USA), three most common in Lithuania types of asphalt pavement structures were selected for estimation of Pavement construction costs. Type No 1 - 7 meters width, $6 \mathrm{~cm}$ thickness asphalt concrete $0 / 16-\mathrm{Vn}$ base course with a $12 \mathrm{~cm}$ thickness crushed dolomite subbase and a minimum of $8 \mathrm{~cm}$ thickness leveling course of enriched gravel. Economic construction cost of this type of pavement under 1996 price level was 288.3 thousand litas per kilometer and average yearly roughness was $3.5 \mathrm{~m} / \mathrm{km}$ IRI. Type No 2: 6 meters width base course of double surface dressing with crushed dolomite, $12 \mathrm{~cm}$ thickness subbase of gravel stabilized with cement and emulsion and a minimum of $8 \mathrm{~cm}$ thickness leveling course of enriched gravel. Economic construction cost of this type of pavement under 1996 price level was 143.4 thousand litas per kilometer and average yearly roughness was $5.5 \mathrm{~m} / \mathrm{km}$ IRI. Type No 3: 6 meters width, $4 \mathrm{~cm}$ thickness asphalt concrete $0 / 11-\mathrm{V}$ base course, $12 \mathrm{~cm}$ thickness subbase of gravel stabilized with cement and emulsion and a minimum of $8 \mathrm{~cm}$ thickness leveling course of enriched gravel. Economic construction cost of this type of pavement under 1996 price level was 238.6 thousand litas per kilometer and average yearly roughness was $3.5 \mathrm{~m} / \mathrm{km}$ IRI. Pavement types were based on real projects of laying asphalt pavements on existing gravel roads. The assumption was made that analysed gravel roads should meet the requirements of design standards and no reconstruction is required.

Paved road maintenance expenses were estimated as an average of Ukmergé, Kaišiadorys and Kelmé regions expenses for maintenance of paved regional roads. Based on survey of maintenance expenses, the assumption was made that paved road routine maintenance does not depend on trafic volume and equals to economic cost of 2.2 thousand litas per kilometer per year under 1996 price level. Time periods between repairs and repair costs were taken from standard requirements and price catalogues. Because there was no local data on the repair periods of the second and third asphalt pavement structure types, the required data was taken from the countries with a similar climatic conditions (Finland and the State of Minnesota, USA) where such pavement types were applied from earlier.

Savings in gravel road maintenance expenses were estimated as an average of Ukmergè, Kaišiadorys and Kelmè regions expenses for maintenance of 
regional gravel roads. Based on survey of maintenance expenses, the assumption was made that starting from AADT of $200 \mathrm{veh} /$ day gravel road routine maintenance expenses ( 1.1 thousand litas per kilometer per year) increase in one fourth for each $100 \mathrm{veh} / \mathrm{day}$ and equals to the paved road routine maintenance expenses at AADT of $600 \mathrm{veh} /$ day. (Additional expenses for blading allows to keep the average pavement roughness throughout all blading season app. 8-9 months.) Time periods between repairs were used according to standard requirements and existing practice. Repair costs were estimated according to local price catalogues.

\subsection{Economic research}

Economic research comprised two parts: 1) analysis and approval of the most appropriate economic feasibility evaluation methods and criteria, 2) selection of road investment appraisal components.

Research of economic feasibility evaluation methods and criteria concluded that under limited budget conditions the Internal Rate of Return should be selected as the most important criteria for the decision making on paving of gravel roads. Secondary recommended criteria were: Net Present Value, Construction Cost and Cost/Benefit Ratio. A 20-year road investment appraisal period, discount rate of $10 \%$ and annual $\mathrm{AADT}$ increase in $7 \%$ were proposed for the model calculations.

Substantiation of road investment appraisal components was based on their importance and current scientific reliability of monetary valuation possibilities. It was concluded that six components to be included into the Lithuanian model for economic evaluation of the feasibility of paving gravel roads. These were:

Pavement construction costs;

Paved road maintenance expenses;

Savings in gravel road maintenence expenses;

Savings in vehicle operating costs;

Savings in journey time;

Benefits from minimisation of dust and other environmental pollution.

The first three components were explained under the Road Engineering Research paragraph. The last three components are closely related to transport economy. They are shortly presented below.
Savings in vehicle operating costs were calculated using the VOC Submodel Version 4.0 of the World Bank Highway Design and Maintenance Standards Model HDM-III, with an input of the required data on local vehicle fleet, measured road and traffic parameters. Savings were computed as a difference between VOC on existing gravel road sections versus VOC on more even paved roads. It was assumed that traffic flow and the composition of different vehicle types in a traffic does not change after paving, except the model of a bus. Due to a high ground clearance commonly used on gravel roads the bus of "LAZ" model in economic evaluation was changed to that of "Ikarus" model used on paved roads.

Savings in journey time were estimated using the curves of relationship between travel speed and road roughness on gravel and earth roads presented in the World Bank HDM-III model and locally accepted relationships between vehicle speeds (or allowed speeds) and roughness on paved roads. The difference of speed on the same gravel and paved road sections resulted in certain amount of time savings, which were expressed in monetary terms. Data required for estimating journey time savings consisted of AADT, traffic flow composition, vehicle occupancy rates and data on working and non-working time for occupants of different vehicle types. It was assumed that the traffic flow composition as well as vehicle occupancy rates should be the same before and after paving of a gravel road.

Benefits from minimisation of dust and other environmental pollution were estimated using program EKOL. The program assessed impacts of negative transport-generated pollution on human health, industry, public utilities and plantings in money terms. The following pollution components were assesed: noise, $\mathrm{CO}, \mathrm{NO}, \mathrm{C}_{\mathrm{n}} \mathrm{H}_{\mathrm{m}}, \mathrm{SO}_{2}, \mathrm{~Pb}, \mathrm{~B}(\mathrm{a}) \mathrm{p}$, inorganic compounds and solid particles. Program output depended on AADT, traffic flow composition and the type of roadside surroundings. The type of an average for Lithuania gravel road surroundings reflected the research on roadside surroundings data collected in test regions. The average Lithuanian roadside surroundings, AADT equal to $300 \mathrm{veh} / \mathrm{day}$ and a gradient equal to $0 \%$ were used for model calculations. Based on the data of research and publications done by British, Finnish and Lithuanian scientists, it was assumed that the sum of losses generated by more frequent vehicle speed changes under rough gravel 
road conditions, a more rapid deterioration of vehicle parts and losses generated by dust impact, on gravel roads were 1.2 time bigger than that on paved roads with the same AADT and traffic flow composition.

\section{Model structure}

The essence of the model was relatively simple. Six interacting cost and savings sub-models were added together over a 20-year period in discounted present values with unit costs determined at 1996 prices.

Creation of the mathematical model for evaluation of an economic feasibility of paving of gravel roads was founded on the principles of reliability, simplicity and applicability.

Main model parts are 6 major data sets, 6 submodels representing 2 cost and 4 savings components and the stage of cost/benefit analysis (see Fig). 6 major data sets comprise a total of 15 minor data sets, which total 79 data set elements (excluding HDM and E Data Set elements). Initial model computations were based on running the model with an application of the three different values to the three data set elements - AADT of a gravel road to be paved, gravel road roughness and asphalt pavement type to be applied. These elements were called independent variables. The values of independent variables were:

AADT of a gravel road to be paved: $200 \mathrm{veh} / \mathrm{day}$, $500 \mathrm{veh} /$ day, $800 \mathrm{veh} /$ day;

gravel road roughness: $5 \mathrm{~m} / \mathrm{km}$ IRI, $8 \mathrm{~m} / \mathrm{km}$ IRI, $11 \mathrm{~m} / \mathrm{km} \mathrm{IRI}$;

asphalt pavement structure types: type No 1 (roughness $-3.5 \mathrm{~m} / \mathrm{km} \mathrm{IRI),} \mathrm{type} \mathrm{No} 2(5.5 \mathrm{~m} / \mathrm{km}$ IRI), type No 3 ( $3.5 \mathrm{~m} / \mathrm{km}$ IRI).

Independent variables influenced dependent variables whitch were functionally connected with the first five sub-models and were used in estimation of data for input into the cost/benefit analysis stage of KAMIS model. In initial model computations a main seekable the Internal Rate of Return maximum value.

KAMIS - the name of the model is coming from the Lithuanian abbreviation Keliu Asfaltavimo ModeIIS (the closest meaning in English would be - Road Paving Model). Model mathematical expression is presented in formula 4.

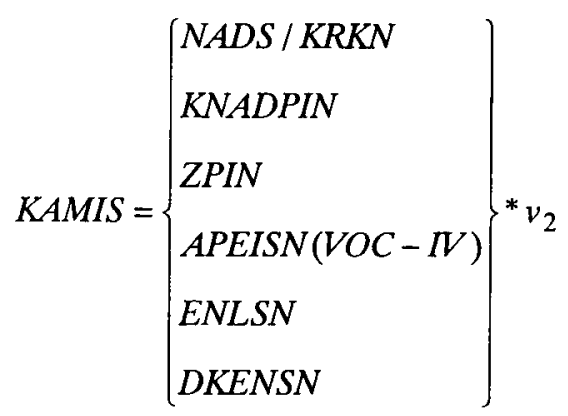

where

$N A D S / K R K N$ - submodel for determination of pavement construction cost;

$K N A D P I N$ - submodel for estimation of paved road maintenance expenses;

$Z P I N$ - submodel for estimation of gravel road maintenance expenses;

$A P E I S N(V O C$-IV) - submodel for computation of vehicle operating cost savings;

$E N L S N$ - submodel for determination of journey time savings;

DKENSN - submodel for computation of benefits from minimisation of dust and other environmental pollution;

$\mathrm{v}_{2}$ - discount factor;

* - sign of multiplication.

KAMIS scheme is presented in Fig.

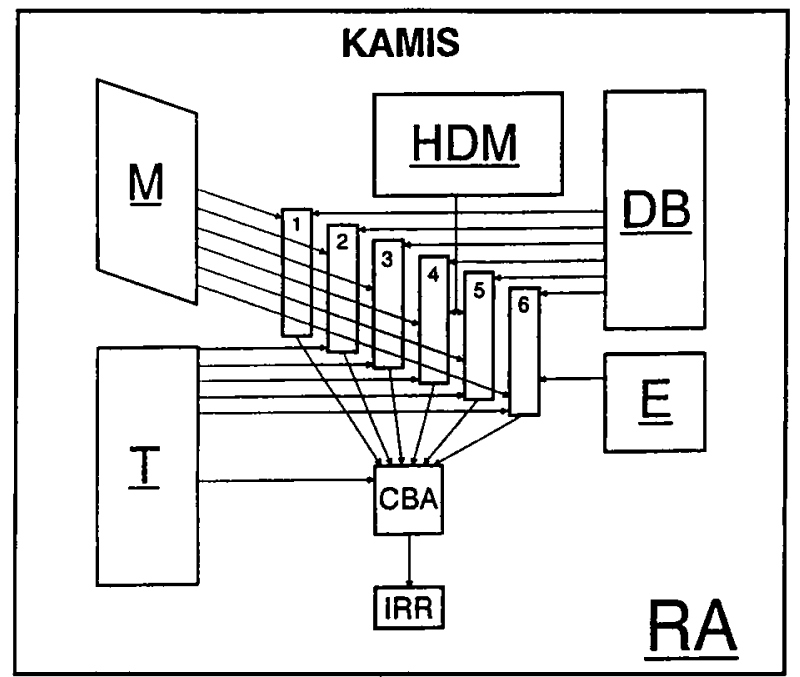

Scheme of KAMIS model computations algorithm under the limited budget conditions [2]: $\mathbf{T}$ - Paving Timing and Economic Valuation Criteria Data Set; $\mathbf{M}$ - Measurement Data Set; HDM - HDM Data Set; DB - Unchangeable Data Bank; $\underline{\mathbf{E}}$ - Evaluation of Environmental Losses Data Set; $\underline{\mathbf{R A}}$ - Model Application Restriction Area Data Set; CBA Cost/Benefit analysis; IRR - Internal Rate of Return; 1 Submodel NADS/KRKN; 2 - Submodel KNADPIN; 3 Submodel ZPIN; 4 - Submodel APEISN(VOC - IV); 5 Submodel ENLSN; 6 - Submodel DKENSN 


\section{Results}

Preliminary results of KAMIS were announced in late 1995. Creation of KAMIS model has exposed the economic benefits of paving of high volume and rough gravel roads and grounded gravel roads paving programs. Model has allowed to evaluate economic feasibility of gravel roads meeting the requirements of design standards. It was estimated that:

1) according to the World Bank requirements for the investment projects in Lithuania (Internal Rate of Return should be more than 10\%), at 1996 unit prices paving of gravel road was feasible when average gravel pavement roughness was $11 \mathrm{~m} / \mathrm{km}$ IRI and AADT exceeds $300 \mathrm{veh} /$ day, and when roughness was 10 $\mathrm{m} / \mathrm{km} \mathrm{IRI} \mathrm{and} \mathrm{AADT} \mathrm{exceeded} 400 \mathrm{veh} / \mathrm{day}$;

2) under the limited budget conditions (IRR > 12\%), at 1996 unit prices paving of gravel road was feasible when average gravel pavement roughness was $11 \mathrm{~m} / \mathrm{km}$ IRI and AADT exceeded $350 \mathrm{veh} /$ day, and when roughness was $10 \mathrm{~m} / \mathrm{km}$ IRI and AADT exceeded $450 \mathrm{veh} /$ day;

3) the Internal Rate of Return maximum value was equal to $41 \%$ when a combination of independent variables was as follows: AADT - $800 \mathrm{veh} /$ day, gravel road roughness $-11 \mathrm{~m} / \mathrm{km}$ IRI and asphalt pavement structure type No 2 .

Gravel road condition research data has served as a technical basis and the Model served as an economic basis for initiation of the Program of Paving Gravel Roads in Lithuania. In 1996 KAMIS model was first introduced in the State Enterprise "Šiauliu regiono keliai" for the selection of gravel roads for their further inclusion into the paving program starting from 1997. The Model was applied for the evaluation of economic feasibility of paving of the preselected gravel roads. It was estimated that economic investment cost for paving of $61.2 \mathrm{~km}$ of gravel roads would total 11.4 million litas, but the Net Present Value (NPV) of the Program in a 20-year analysis period at a discount rate of $10 \%$ using 1997 unit prices would exceed 4.6 million litas.

At the end of 1997 KAMIS model was used for economic evaluation of Gravel Road Paving Program financed by the Lithuanian Road Fund and the European Investment Bank loan. It was estimated that paving of the total of $253.7 \mathrm{~km}$ of Lithuanian gravel roads in 1998 should cost 72.4 million litas at 1997 economic prices and 78.6 million litas at 1997 financial prices. The NPV at a discount rate of $10 \%$ should amount to 170.2 million litas and at a discount rate of $15 \%$ should amount to 95.3 million litas.

Model development and application in wide range of bodies of the Lithuanian Road Administration has resulted in a spread of the road construction and maintenance costs, road users benefits and environmental losses optimisation philosophy.

\section{Conclusions}

1. Based on the experimental research data of 1994-1995, it was determined that $42 \%$ of State gravel roads were in good condition, $40 \%$ in satisfactory condition and $18 \%$ in poor condition. According to the international roughness index, average roughness of gravel road test sections varied between 5.6 and 12.5 $\mathrm{m} / \mathrm{km}$ IRI. It was proved that gravel pavement roughness reflects road technical condition, quality of local soils and pavement aggregate mix, genesis of gravel quarries, efficiency of road maintenance and depends on the traffic volume.

2. Mathematical model - KAMIS - was created for the evaluation of economic feasibility of paving gravel roads under Lithuanian conditions. Model estimates renovation expenses and savings based on road technical condition, road pavement roughness and traffic parameters. In comparison with other wellknown models or systems, currently used for appraisal of paving of gravel roads, KAMIS model evaluates wider range of cost and benefit components and is applicable under "freezing climate" conditions.

3. Running of the Model allowed:

3.1. to evaluate economic feasibility of paving gravel roads, meeting the requirements of design standards, from the road maintenance, road users and environmental point of view;

3.2. to define the threshold value between those gravel roads where paving is feasible and those where asphalt pavement is not justified:

3.2.1. according to the World Bank requirements for the investment projects in Lithuania (Internal Rate of Return should be more than $10 \%$ ), at 1996 unit prices paving of gravel road is feasible when average gravel pavement roughness is $11 \mathrm{~m} / \mathrm{km} \mathrm{IRI} \mathrm{and}$ AADT exceeds $300 \mathrm{veh} /$ day, and when roughness is $10 \mathrm{~m} / \mathrm{km}$ IRI and AADT exceeds $400 \mathrm{veh} /$ day; 
3.2.2. under the limited budget conditions (IRR $>12 \%$ ), at 1996 unit prices paving of gravel road is feasible when average gravel pavement roughness is $11 \mathrm{~m} / \mathrm{km}$ IRI and AADT exceeds $350 \mathrm{veh} /$ day, and when roughness is $10 \mathrm{~m} / \mathrm{km}$ IRI and AADT exceeds 450 veh/day.

3.3. to monitor operating costs of different vehicles and the time losses of their passengers in various road sections or routes.

4. The Internal Rate of Return was grounded to be the most important criteria for the decision-making on paving of gravel roads under the limited budget conditions. Secondary recommended criteria were: Net Present Value, Construction Cost and Cost/ Benefit Ratio.

5. KAMIS model was implemented and was used in several organisations of Lithuanian Road Administration (LRA, Regional Road Districts and State Enterprise "Transport and Road Research Institute"). The creation of the Model had an impact on developing the state strategy of paving of gravel roads in Lithuania and served as a basis for its economic justification.

6. After application of the Model in Programs of Paving of Gravel Roads in 1997 and in 1998, their economic feasibility was established. The Net Present Value of laying of an asphalt pavement on $61.2 \mathrm{~km}$ of gravel roads in 1997 and on $253.7 \mathrm{~km}$ (total $314.9 \mathrm{~km}$ ) in 1998, in a 20 -year appraisal period at a discount rate of $10 \%$ and using the 1997 unit prices should total 174.8 million litas. In addition to the measured economic effect, other intermediate goals were foreseen. Paving of gravel roads would serve for decreasing unemployment rate and improving the country's image, would decrease the losses in transportation of agricultural produc-tion, would facilitate in better communication possibilities for rural inhabitants and in economic growth of areas more comfortable for transportation.

\section{Acknowledgements}

In the person of the Professor Ph D Sulevy Lyly authors would like to thank the Department of Environmental Engineering and Surveying of the Helsinki University of Technology for the basic support in theoretic research. Special thanks and appreciation is expressed to the staff of SE "Transport and Road Research Institute” headed by Mr Virgaudas Puodžiukas,
General director of the Lithuanian Automobile Road Administration, Mr Gintaras Striaukas and his employees for encouragement and assistance in reaching the research objectives. Personal thanks for understanding and research support to Mr Peter Arlidge, Mr Valdas Kezys, Mr Vytautas Petružis, Mr Algis Orlickas, Prof Wladimir Segercrantz and Prof Algirdas Škys.

\section{References}

1. S. Skrinskas, V. Puodžiukas. Rusiško nelygumo matavimo prietaiso PKRS-2u kalibravimo pagal tarptautinio nelygumu indekso (IRI) skalę tyrimai // Keliai ir geležinkeliai. 2-oji tarptautine konferencija "Miestu inžinerija ir aplinka". Vilnius: Technika, 1996, p. 98-100.

2. S. Skrinskas. Research of the Condition of Lithuanian Gravel Roads and Feasibility of their Renovation. Summary of Doctoral dissertation. Vilnius: Technika, 1998. $32 \mathrm{p}$.

Itteikta 19980424

\section{LIETUVOS ŽVYRKELIAI IR JU ASFALTAVIMO TIKSLINGUMAS}

\section{K. Sakalauskas, S. Skrinskas}

\section{Santra u k}

Straipsnyje pateikiami ir analizuojami Lietuvos žyyrkelių technines būklès tyrimų rezultatai. Moksliškai pagrindžiamas dangos lygumo - svarbiausio žvyrkeliu būklès techninio bei ekonominio rodiklio - taikymas žvyrkeliụ asfaltavimo ekonominiam tikslingumui vertinti. Asfaltines dangos įrengimo tikslingumui nustatyti žvyrkeliuose buvo atlikti eismo stebejjimai, kelio pločio, žvyro dangos sluoksnio storio, žvyro mišinio granuliometrinès sudeties, molio, dulkių ir dumblo kiekio, vandens nuleidimo sistemos irenginiu, kelio sankasos būklès, reikalingo sustojimo matomumo bei dangos lygumo tyrimai. Pažymima, kad tyrimuose pirmą kartą Lietuvoje žvyro bei asfaltinès dangos lygumas buvo nustatytas pagal tarptautinę nelygumų indekso IRI skalę. Tyrimụ duomeny pagrindu apskaičiuota žvyro dangos nelygumu didejjimo, išlyginus greideriu, kreive, taikytina vidutiniam žvyrkelio lygumui nustatyti.

Antroje straipsnio dalyje aprašomas teoriniais bei eksperimentiniais tyrimais pagristas Lietuvos ekonomines bei klimatines sąlygas atitinkantis žvyrkelių renovacijos ekonominio tikslingumo vertinimo modelis KAMIS. Pateikiami trumpi išlaidų bei santaupu submodelių bei modelio esmès aprašymai, modelio matematine išraiška ir algoritmo schema. Nustatytas pagrindinis žxyrkelių renovacijos ekonominio tikslingumo vertinimo kriterijus riboto biudžeto sąlygomis - vidinès grąžos norma.

Tyrimu metu gauti tarpiniai rezultatai Lietuvos keliu imonèse naudojami nuo $1995 \mathrm{~m}$., o modelis idiegtas $1997 \mathrm{~m}$. Pagal KAMIS, 1997 bei 1998 metu žvyrkeliu asfaltavimo programų bendras ekonominis efektas 20 -ies būsimu metu laikotarpiu $1997 \mathrm{~m}$. kainomis turètų viršyti $174 \mathrm{mln} . \mathrm{Lt}$. 
Kazys SAKALAUSKAS. Doctor, Associate Professor, Department of Road Engineering, and dean of Faculty of Environmental Engineering, Vilnius Gediminas Technical University (VGTU, formely VTU), Sauletekio al. 11, 2040 Vilnius, Lithuania.

Doctor of Technical sciences (road engineering), Leningrad, Institute of Railways, 1966. Employment: senior lecturer, Kaunas Polytechnic Institute (KPI). Associate Professor (1969), head of Department of Road Engineering, dean of a faculty, Vilnius Civil Engineering Institute (VISI, now VGTU). Publications: author of over 100 scientific articles, co-author of the manual "Road Maintenance", author of the book "Railway Engineering". Conferences: about 30 scientific reports at various conferences and symposiums.
Skirmantas SKRINSKAS. VGTU Dept of Roads, research assistant. Vilnius Gediminas Technical University, Sauletekio al. 11, 2040 Vilnius, Lithuania.

A graduate of Vilnius Civil Engineering Institute (VISI). Since 1989 head of the laboratory of highway materials in VISI. In the period from 1992 to 1997 doctoral student at Vilnius Gediminas Technical University (VGTU). Master degree in 1992. From 1992 to 1995 doctoral studies according to the program of Helsinki University of Technology. In the period from 1993 to 1997 senior specialist and inspector of Lithuanian Automobile Road Administration (part-time job). Since 1997 research assistant of the Department of Roads of VGTU. Probation in Faeroe Islands (Denmark) (Landsverkfrodingurin), Finland (Helsinki University of Technology, twice) and the USA (Minnesota Department of Transportation and University of Minnesota). Author or co-author of 1 study guide and 12 articles. Research interests: road engineering, road and transportation investment appraisal and management. 